Living with the "Enemy":

An Analysis of Foreign Investment in the Japanese Equity Market

Yasushi Hamao

\&

Jianping Mei

Working Paper No. 100

Yasushi Hamao is Associate Professor of Finance at Columbia Business School

Jianping Mei is an Associate Professor of Finance at the Stern School of Business, New York University

Working Paper Series

Center on Japanese Economy and Business

Graduate School of Business

Columbia University

December 1995 


\title{
Living with the "Enemy":
}

\section{An Analysis of Foreign Investment in the Japanese Equity Market}

\author{
Yasushi Hamao and Jianping Mei*
}

First Draft: December 12, 1994

This Version: October 1, 1995

\begin{abstract}
This paper studies the impact of foreign investment on domestic financial markets. It examines the empirical validity of some protectionist claims used by regulators to restrict foreign investment. These people argue that 1) trading by foreign investors tends to increase market volatility more than trading by domestic investors, 2) foreign investors have sophisticated investment technology to which domestic investors do not have access so that domestic investors tend to "lose" to foreign investors, and 3) foreign investors tend to be short term investors whose investments are mostly driven by expectation of short-term gains rather than long-term fundamentals such as corporate dividend growth. We find there is no evidence supporting these claims from the Japanese experience. To the contrary, we find that foreign investors tend to be long-term contrarian players in the market and their presence helps to improve liquidity in the Japanese market. Thus, our results support the hypothesis that international free flow of equity capital is beneficial to domestic markets.
\end{abstract}

Keywords: Excess Return Decomposition, Market Timing, Volatility

*Graduate School of Business, Columbia University, New York, NY 10027, (212) 854-5631 and Stern School of Business, New York University, 44 West 4th Street, New York, NY 10012-1126, (212) 998-0354, respectively. We thank the Tokyo Stock Exchange and Daiwa Securities for providing some of the data, Michael Adler, Warren Bailey, Stephen Cecchetti, Jeffrey Frankel, Takatoshi Ito, Anthony Lynch, Kenneth Singleton, and participants at the 1995 Summer Institute at the National Bureau of Economic Research for helpful comments and conversations. 


\section{Introduction}

Many theoretical and empirical works in finance have demonstrated the fact that international diversification brings enormous benefits to portfolio investors. ${ }^{1}$ A recent economic study by Obstfeld (1994) also shows that international diversification allows risk-averse investors to take risky projects in developing countries, helping to spur economic growth in these countries. Few studies, however, have systematically examined the impact of foreign equity portfolio investment on domestic financial markets. This is an important issue, particularly given the fact that stock prices of many emerging markets recently have declined dramatically as a result of foreign money outflow, causing severe financial disruption to these economies. This raises a serious question about whether international "hot money" really facilitates long-term market development in emerging markets. ${ }^{2}$ The presence of foreign investment barriers in many countries suggests that government regulators in these countries have serious doubts about the long-term benefits of foreign investment.

Financial authorities in these vulnerable emerging markets often argue that foreign portfolio investment would increase market volatility, hence exposing them to unduly high risk. Another concern the authorities may have is that the investors in developed markets have sophisticated investment technology to which domestic investors do not have access so that domestic investors tend to "lose" to foreign investors. This creates a serious political problem in many countries, which makes it difficult for open-market reform. Emerging market regulators

\footnotetext{
${ }^{1}$ See, for example, Bailey and Stulz (1990), Eun and Resnick (1988), Grauer and Hakansson (1987), Hardy (1990), Harvey (1995), and Stulz (1987).

2 "Private-Capital Flows Can Hurt Poor Nations", Wall Street Journal, January 30, 1995.
} 
are also concerned that foreign investors tend to be short-term players whose presence in the market today may not be warranted tomorrow. As a result, capital controls are observed in many countries. Korea, for example, limits foreign ownership to ten percent. For many large stocks this limit is reached but the government's process of raising the limit has not been swift. Another type of regulation is found in Thailand where foreigners' investment is restricted to a different class of shares which are traded on a separate exchange. ${ }^{3}$ A similar regulation exists in China. High withholding taxes in investment gains are another form of restriction against foreign investment. $^{4}$

In this paper, we study the empirical validity of some of those arguments by examining foreign investment behavior in the Japanese stock market. We evaluate and contrast this behavior with that of Japanese domestic sectors. The questions we ask are: (1) Do foreign investors demonstrate different behavior? Especially, are they short-term oriented in their investment horizon? (2) How do domestic and foreign investors fare in their investment results? And (3) Is there evidence that foreign investors cause higher volatility in the domestic market?

There may also be other concerns and claims by regulators of financial markets, such as protection of domestic financial institutions against their foreign competitors. Here we focus on the above three questions since they are general in nature, and are often asked in the context of open-market reforms of emerging markets.

Of course, the Japanese market is no longer an "emerging" one; its size has increased

${ }^{3}$ Bailey and Jagtiani (1994) document capital market segmentation in the Thai stock market. ${ }^{4}$ See Harvey (1995) for a description of various capital restrictions in the emerging markets. 
substantially in the last 30 years. But our data dates back to the early 1970s when the market was much smaller and more tightly regulated against foreign investment. Our sample period encompasses the gradual deregulation of the Japanese market especially with regard to foreign investment. Following a significant amendment to the Foreign Exchange Control Law that took effect at the end of 1980, Japan is now, in principle, open to foreign ownership. Reflecting this change, foreign ownership in Tokyo Stock Exchange listed firms increased from $2.5 \%$ in 1979 to $6.3 \%$ in 1983.5 In addition, as noted later, our data on trading volume show a significant increase in trading activities by foreign investors in recent years. By examining the behavior of overseas investors in the Japanese market, we can study the impact of foreign investment on domestic financial markets. One clarification is in order at this point. We are using more than 15 years of monthly data to examine long-term behavior of foreign investors and its impact on the domestic market. We are, however, not examining short-term (day-by-day or minute-by-minute) behavior of foreign investors, such as index futures arbitrage transactions. ${ }^{6}$

The paper is divided into five sections. Section 2 describes data and presents some

${ }^{5}$ Tokyo Stock Exchange (1994b). Kang and Stulz (1995) examine foreign ownership in Tokyo Stock Exchange listed firms.

${ }^{6}$ In the early 1990s Japanese regulators introduced several measures to discourage transactions in the stock index futures market on the ground that the arbitrage transactions in the futures market are causing excessive volatility in the spot market. Because of the high transactions costs and taxes, arbitrage is usually only profitable for proprietary dealings by securities houses (see Brenner, Subrahmanyam, and Uno (1989)). Since foreign securities houses are active in the futures market, these measures can be partly viewed as regulations against them. As stated in the text, we do not address this point. Our definition of foreign investors is long-term players such as mutual and pension funds, and proprietary transactions by foreign securities firms are classified as "securities firm proprietary dealing (domestic and foreign)." See also Miller (1994) for a criticism of Japanese securities regulation. 
summary statistics on Japanese stock market performance and trading behavior of Japanese and foreign investor groups. Section 3 discusses the impact of trading on market volatility by major investor groups. Section 4 discusses the application of the market timing test of Henriksson and Merton (1981) in evaluating the market timing ability of Japanese and foreign investor groups in the Japanese market. Section 5 first presents an approximate present value model in which we decompose excess returns into three different components: innovations (or news) about dividend growth, interest rates, and future expected returns. We then study the relationships between trading behavior and various innovations in security returns. The final section concludes the paper.

\section{The Data}

We use data on trading by different types of investors on the Tokyo Stock Exchange from 1974:07 to 1992:06. The yen amount of purchases and sales during the month are recorded each month for proprietary trading of securities firms and trading at their clients' orders. The latter is further classified into insurance companies, banks, other financial institutions, investment trusts (mutual funds), non-financial corporations, other firms, non-Tokyo Stock Exchange member securities firms, individuals, and foreigners. The original data are obtained from the Tokyo Stock Exchange Monthly Statistics (1975-1993). It is compiled from reported trading figures of socalled "integrated securities firms." The integrated securities firms are large securities houses capable of lead-underwriting securities and licensed in all lines of business (proprietary dealing, brokerage, sales, and underwriting) in the Tokyo market. Although the data do not contain 
tradings by small "non-integrated" firms, the proportion of such transactions is relatively small. ${ }^{7}$

In order to focus on distinctively different types of investors, we will limit the number of investor types and use the data for (1) securities firms (proprietary dealing), (2) insurance companies, (3) banks, (4) investment trusts, (5) non-financial corporations, (6) individuals, and (7) foreigners. The bank sector represents investment by the banks themselves (up to 5 percent of any corporation) and institutional client accounts they manage. While it is not possible to break down the two, it is reasonable to assume that the majority of the trading is for client accounts, given the stationary nature of the banks' own holdings of equities. The investment trusts are essentially the same as mutual funds. The foreigner sector includes both institutions and individuals. Again, although it is not possible to divide the two, it is reasonable to consider most of it to be institutional, in the form of mutual and pension funds. ${ }^{8}$

For monthly aggregate stock returns, we use a value-weighted index (dividend reinvested) of the Tokyo Stock Exchange Section I stocks. For short-term interest rates, we use Gensaki rates. These data are obtained from Hamao and Ibbotson (1989). The S\&P 500 total returns are obtained from Ibbotson (1994).

Table 1 presents trading volumes as a percentage of total trading volume by the "integrated security companies." We observe several interesting points. First, many Japanese institutions

\footnotetext{
${ }^{7}$ The percentage of trading volume by integrated firms of total volume was approximately $70 \%$ in the 1970s. It has increased over the years to account for $90 \%$ in 1990s. See Tokyo Stock Exchange (1994a).

${ }^{8}$ Proprietary trading by foreign firms, which was well-noted in the popular press from the late 1980s especially in connection with the index arbitrage, belongs to category (1) securities firms (proprietary dealing).
} 
significantly increased their relative trading volume (an indication of increase in overall holdings) from 1975 to 1988 while dramatically lowering their trading volume in the post-crash year of 1991. For example, Japanese bank (corporation) purchases accounted for only $1 \%$ (6\%) of total purchases in 1975 . The number increased dramatically to $19.8 \%(10.9 \%)$ in 1988 , while dropping significantly to $12.9 \%$ (6.5\%) in 1991 . It is worth noting that, due to the $65 \%$ drop in overall trading activity, the total purchases of banks (corporations) dropped by an astonishing $78 \%$ (82.5\%) from 1988 to 1991 !

Second, foreign investors were the only major investor group which significantly increased its trading share during the post-crash years. Moreover, they were the largest net buyer of Japanese equities. Figure 1 presents the trading activity of foreign investors over the entire sample period. We can see that foreign transactions were quite limited during the relatively restrictive environment of the pre-1980s, accounting for less than $10 \%$ of the monthly transactions. However, the market share picked up significantly during the 1980s and reached a peak of $25 \%$ during the post-crash year of 1992, when the Japanese market was overwhelmed with pessimism. We can also see from Figure 1 that before the market crash foreign investors were quite consistently selling more stocks than they were buying them. This behavior changed after the crash, turning into a net purchaser.

It is worthwhile to note that the percentage of foreign ownership of Japanese stocks remained at a rather low level for the entire period. As shown in Figure 1, except for the increase after the deregulation of the Foreign Exchange Control Law in December 1980, foreign ownership 
remained low compared to foreigners' share in trading volume. ${ }^{9}$ Foreign investors participate in the Japanese market much more actively as "traders" than as "stable shareholders." This may lead to the conjecture that foreigners are short-term oriented and can cause volatility by their trading activities. We examine the validity of this conjecture in the following sections.

Table 2 presents the correlations of net purchases among various types of investors. We observe that foreign investors' net purchases were negatively related to most of Japanese domestic investor groups. ${ }^{10}$ They tend to sell stocks when other Japanese domestic institutional investors are buying. Thus, by generally taking the opposite position, foreign investors improve liquidity and lower volatility in the Japanese market. In addition, we can see that individual investors in Japan also tend to supply liquidity to the market.

\section{Impact on Market Volatility by Foreign Trading}

One of the major concerns of governments around the world about foreign investment in domestic equities is that foreign investors tend to be short-term players whose trading activity increases market volatility. In the Japanese market, transactions by foreign investors have become more active in recent years. There have been several accounts in the popular press that the

\footnotetext{
${ }^{9}$ The year-end holdings data are obtained from Tokyo Stock Exchange (1994b).

${ }^{10} \mathrm{We}$ note that the net purchase series may not be stationary due to the dramatic rise in price and overall shares in the Japanese market. Thus, we have also performed our analysis using the difference between $\log$ (buy) and $\log$ (sell) instead of net purchase. The results are quite robust. Thus, we present the net purchase results and make the other results available upon request.
} 
behavior of foreign investors is a significant factor determining market movements. ${ }^{11}$

To see whether trading activities by foreign investors cause higher volatility, we perform the following regression analysis:

$$
v_{t}=b_{1}+b_{2} v_{t-1}+b_{3} w_{t}+u_{t}
$$

where $v_{t}$ is the monthly volatility for month $t, w_{t}$ is a vector of monthly transactions by various major investment groups, and $u_{t}$ is the error term. We include the lagged volatility to take into account the persistence in monthly volatilities. It is worth noting that $w_{t}$ in the equation could be endogenous. This is because investors' transactions during the month could be affected by the return volatility of the month. This endogeneity could cause the $w_{t}$ term to be correlated with the error term in the regression. If this is the case, then OLS regressions could be biased and inconsistent.

To solve the endogeneity problem, we use a 3SLS (three-stage-least-squares) instrumental variables regression technique, modified from Holtz-Eakin, Newey, and Rosen (1988), to accomplish the estimation task. If the data satisfy the orthogonal condition and other regularity conditions in Newey and West (1987), the estimates will be consistent despite the presence of heteroskedasticity and serial correlations.

Intuitively, the estimation procedure is a special case of the generalized method of moments (GMM) estimation technique. In the first stage, a simple instrumental-variables

\footnotetext{
${ }^{11}$ For example, "Foreign Money Inflow Brings Active Investment," April 10, 1993, "Foreign Money Escapes From Tokyo Market, Causing Market Drop," June 22, 1993, "Foreigners Actively Buying Export and Hi-Tech Stock," December 17, 1993 (all in Nihon Keizai Shimbun (Japan Economic Journal)).
} 
regression is used to obtain an estimate of (1), ignoring heteroskedasticity and serial correlations. In the second and third stages, we use moving averages of the residuals from the first-stage regression to calculate a Newey-West adjustment matrix. We then use a generalized-least-squares (GLS) method to obtain a more efficient estimate of the autoregression for all periods. A detailed description of the estimation procedure is given in the appendix.

The first row of Table 3 reports the regression of monthly volatility on lagged volatility and contemporaneous net purchases (Net Buy) by various groups. Monthly volatility is measured by a rolling 25 -day variance of daily returns of the Nikkei 225 index. ${ }^{12}$ We can see that there is no evidence that foreign net purchases affect volatility more than net purchases of domestic groups. As a matter of fact, foreign net purchases tend to have a smaller impact on volatility relative to domestic net purchases. The second row of Table 3 reports the regression of monthly volatility on lagged volatility and contemporaneous purchases (Buy) by various groups. We can see that there is also no evidence that foreign purchases affect volatility more than purchases of domestic groups. The third row of Table 3 reports the same regression using sales. Here we do have some evidence that foreign sales tend to increase market volatility more than domestic sales. However, the difference in impact between foreigners and Japanese Insurance Firms (or Securities Firms) is not statistically significant. Thus, we find little empirical evidence from the Japanese experience suggesting that trading by foreign investors tends to increase market volatility more than that of domestic groups. The point of this exercise is that although there may have been a

\footnotetext{
${ }^{12}$ Due to data availability, we use daily Nikkei 225 index (instead of the value-weighted index) returns to compute this volatility. Nikkei 225 index is a price-weighted average of large and representative 225 stocks on the Tokyo Stock Exchange Section I.
} 
few instances in which foreign tradings have affected market volatility, we have little systematic evidence that foreign tradings tend to increase market volatility more than those of domestic groups.

\section{Evaluating Market Timing Performance of Various Investment Groups}

\section{A. Market Timing: A Preliminary Study}

Another major concern about foreign investment for many governments is that foreign investors have sophisticated investment technology to which domestic investors do not have access. As a result, they have better market timing so that domestic investors tend to "lose" to foreign investors. To protect the interests of domestic investors, restrictions are often placed on foreign investment in domestic companies.

To examine this issue, we first plot excess returns and net purchases by major market groups in Figure 2. ${ }^{13}$ We aggregate investors into three large groups: Japanese institutions (1 through 5 above), Japanese individuals (6), and foreign investors (7). We can see clearly from the chart that foreign and domestic individual investors were major net sellers during the booming 1980s. They sold quite heavily during 1983 - 1990, while Japanese institutions made more and more purchases as the market ran up. As a result, foreigners missed major market booms (while avoiding heavy losses due to the market decline after 1990). In this sense, we have no evidence that foreigners were better market timers.

\footnotetext{
${ }^{13} \mathrm{~A}$ simple and direct approach to this issue would be to examine the returns on investment by various investor groups. However, the return data is not available to us. As a result, we examine the relationship between tradings of various groups with Japanese market movements.
} 
To look at the market timing issue more closely, we examine the relationship between net purchases and future excess returns. We run the following regression for the seven major investor groups.

$$
P U R_{t}=c_{1}+c_{2} P U R_{t-1}+c_{3} e_{t+1, t+j}+\epsilon_{t},
$$

where $P U R_{t}$ is net purchases for month $t$ and $e_{t+1, t+j}(j=1,3,6)$ is future excess return (in excess of short rate) over a one-, three-, or six-month period from month $t$. This specification implies a trading strategy of purchasing stocks based on the forecast of excess returns in the next one-, three-, or six-month holding period.

As can be seen from Table 4, although foreign net purchases appear to be positively related to future excess returns at $t+1\left(c_{3}\right)$, the relationship is not significant. Moreover, the coefficients $c_{3}$ on excess returns $e_{t+1, t+3}$ and $e_{t+1, t+6}$ are negative. There appears to be some evidence that the purchases of Japanese banks and investment trusts are positively related to future excess returns. Overall, there is no evidence that foreign investors as a group possess superior market timing ability.

\section{B. Market Timing: A Non-parametric Test}

Henriksson and Merton (1981) developed a non-parametric test to evaluate investors' market timing performance that only requires the observation of market excess returns and the prediction of forecasters. It does not depend on knowledge of the distribution of excess returns on the market or any particular model of security valuation. Given that the predictions of forecasters are generally unobservable, later studies have tried to use ex post portfolio excess 
return to proxy for the unobservable ex ante predictions. ${ }^{14}$ In this paper, we propose to use an alternative proxy, the net purchase of stocks, in order to evaluate the market timing performance of Japanese institutional and individual investors.

The intuition behind this proxy is that, in a frictionless market where investors are risk neutral and where stock trading only depends on investors' forecasts of future market excess returns, investors increase their positions in stocks if they forecast next period stock excess return to be positive and reduce or close their position in stocks if they forecast next period stock excess return to be negative. Thus, there is a one-to-one correspondence between stock net purchase and investors' predictions of next period market excess returns.

Following Henriksson (1984), we first define $Z_{M}(t)$ to be the one-period return on the market portfolio and $R(t)$ to be the one-period return on riskless securities. We also define $\gamma(t)$ to be investors' investment decision (forecast) variable where $\gamma(t)=1$ if investors decide to increase their position during time $t-1$, and $\gamma(t)=0$ if investors decide to reduce their position during time $t-1$. The two probabilities of interest for $\gamma(t)$ conditional on the realized return on the market are

$$
\begin{aligned}
& p_{1}(t)=\operatorname{prob}\left[\gamma(t)=0 \mid Z_{M}(t) \leq R(t)\right] \text { and } \\
& p_{2}(t)=\operatorname{prob}\left[\gamma(t)=1 \mid Z_{M}(t)>R(t)\right]
\end{aligned}
$$

Thus, $p_{1}(t)$ is the conditional probability of a correct forecast, given that $Z_{M}(t) \leq R(t)$, and $p_{2}(t)$ is the conditional probability of a correct forecast, given that $Z_{M}(t)>R(t)$. Merton (1981) showed

\footnotetext{
${ }^{14}$ See, for example, Henriksson (1984).
} 
that a necessary and sufficient condition for a forecaster's predictions to have no value is that $p_{1}(t)+p_{2}(t)=1$. The existence of forecasting ability will result in $p_{1}(t)+p_{2}(t)>1 .{ }^{15}$

Based on the above theoretical results, Henriksson and Merton (1981) proposed the following test statistic to test the null hypothesis of $p_{1}(t)+p_{2}(t)=1$ :

$$
S=\frac{n_{1}}{N_{1}}+\frac{N_{2}-n_{2}}{N_{2}}-1
$$

where $n_{1}$ is the number of correct forecasts, given $Z_{M} \leq R ; n_{2}$ is the number of times forecast that $Z_{M} \leq R$ subtracting $n_{1} ; N_{2}$ is the number of observations where $Z_{M}>R$; and $N_{1}$ is the total number of observations subtracting $N_{2}$. They have provided asymptotic standard errors for the statistic, thus a simple t-test of the null hypothesis could be formed.

Applying the Merton and Henriksson test, we evaluate the market timing performance of various investment groups in the Japanese market, using net stock purchases as proxy for the ex ante prediction of forecasters. The results are presented in Table 5. We divide the sample into four subperiods so that we can investigate performances during different time periods and study the consistency of these performances. The results are thus presented in four panels. In addition to evaluating the ability to forecast Japanese stock market returns in excess of the short-term rate ("Forecast over short rate"), we also evaluate the ability to forecast Japanese stock market returns

\footnotetext{
${ }^{15}$ For a more thorough presentation of this framework, see Merton (1981) and Henriksson and Merton (1981).
} 
in excess of the S\&P 500 returns in dollars. ${ }^{16}$

Panel A of Table 5 shows that Japanese banks have the best market timing performance while corporations and Japanese individual investors have the worst market timing performance during the sample period of 1974:8 - 1992:6. Foreign investors also demonstrated some degree of market timing ability but the performance is not statistically significant. When we split the sample into two subperiods, 1974:8 - 1983:12 and 1984:1 - 1992:6, we find that securities firms' proprietary trading, investment trusts, and corporations have the worst timing performances in the first subperiod. Corporations and individual investors have the worst market timing performances during the second sample period. Interestingly, we find that foreign investors did relatively well in yen returns during the first sample period when there were restrictions on foreign investment while they did less well in the second time period when there was considerable relaxation of foreign investments. It is easy to see that performances are not consistent over time. $^{17}$

The Japanese stock market experienced dramatic run-ups in the mid-1980s and sharp declines after the beginning of 1990. Thus, it is interesting for us to see the market timing performance for various groups during this time period. From Panel D, we can see that the socalled "Japanese securities power houses" (securities firms) fared the worst during this period of turmoil. Foreign investors also missed their target of market timing with respect to excess returns

\footnotetext{
${ }^{16} \mathrm{We}$ also evaluated the ability to forecast Japanese stock market returns in excess of the longterm bond returns, and in excess of S\&P 500 returns in yen. The results are qualitatively similar to the ones presented here.

${ }^{17}$ This is confirmed formally by a simple calculation of correlations of performances over the two subperiods. The correlations are negative or close to zero for all measures.
} 
in yen. Other groups fared slightly better, but the short sample period prevented us from drawing any statistical conclusions.

In summary, there is little evidence of superior foreign investor market timing abilities. It can be said that the Japanese market was never a successful target of exploitation by foreign investors.

\section{What Determines Investors' Security Trading?}

Some market regulators claim that foreign investors tend to be short-term investors, whose investments are mostly driven by expectation of short-term gains rather than long-term fundamentals such as corporate dividend growth. In this section, we examine the validity of this claim.

We begin by examining the relationship between net purchases and market past excess returns. We regress net purchases by various groups on their lagged net purchases and past returns from month $t-1, t-2$, and $t-3$. The results are presented in Table 6 . We find that, unlike some Japanese investor groups, foreign investments are negatively related to past excess returns. Thus, foreign investors are generally contrarian investors, who tend to sell after a market rally and buy after a market downturn.

To get a closer look at the impact of different excess return components on stock holdings, we use the approximate present value relation of Campbell and Ammer (1993) to decompose unexpected excess stock returns into news about future dividends, interest rates, and future excess 
returns: $:^{18}$

$$
\tilde{e}_{t+1}=\left(E_{t+1}-E_{t}\right)\left\{\sum_{j=0}^{\infty} \rho^{j} \Delta d_{t+1+j}-\sum_{j=0}^{\infty} \rho^{j} r_{t+1+j}-\sum_{j=1}^{\infty} \rho^{j} e_{t+1+j}\right\}
$$

where $r$ is the one-period treasury bill return, $e$ is the excess return on equity (over short rate), and $d$ is the log dividend paid. All variables are measured in real terms and in logs, a tilde $(\sim)$ superscript represents an innovation in a variable, and a delta $(\Delta)$ designates a first difference. Thus $\Delta d$ is the log change in real dividends. We use $E_{t}$ to denote expectations formed at the end of period $t$, while $\left(E_{t+1}-E_{t}\right)$ is the revision in expectations given new information arrived during period $t+1$. The parameter $\rho$ is a constant of linearization that is slightly less than one. ${ }^{19}$

For convenience, we define a simpler notation to refer to the three news components above:

$$
\tilde{e}=\tilde{e}_{d}-\tilde{e}_{r}-\tilde{e}_{e}
$$

Each term in (3) corresponds to one of the summations in (2). Equation (3) says that, ceteris paribus, news that dividends will grow more rapidly in the future would have a positive impact

\footnotetext{
${ }^{18}$ An approximate intertemporal identity is derived by taking a first-order Taylor expansion of an accounting identity for the log one-period return, computing the forward solution of the resulting difference equation in the log of the dividend-price ratio, and applying expectations operators. The only assumption we make here is to impose a consistency condition on expectations that is somewhat weaker than rational expectations. For details, see Campbell and Ammer (1993) or Campbell and Mei (1993).

${ }^{19}$ It is approximately equal to the inverse of the mean of the dividend yield on stocks, or about 0.9988 for the Tokyo Stock Exchange Section I index.
} 
on today's stock return. On the other hand, an unexpected increase in the future expected excess returns (risk premiums) generates an immediate capital loss. Similarly, positive revisions to future interest rate expectations reduce the current return on equity.

In order to determine the relative importance of dividends, real interest rates and future expected excess return innovations on asset returns, Panel A of Table 7 decomposes the variance of unexpected asset returns into six components. The six components are the variance associated with news about future cash flows $\left(\operatorname{Var}\left(e_{d}\right)\right)$, the variance due to news about future real interest rates $\left(\operatorname{Var}\left(e_{r}\right)\right)$, and news about future expected returns $\left(\operatorname{Var}\left(e_{e}\right)\right)$, and the covariances among these three news components. For easier interpretation, the six terms are given as ratios to the variance of the unexpected excess asset returns so that they sum to one. From Panel A, one can observe that a large portion of the variance in unexpected returns is explained by news (or changing expectations) about future dividends for the Tokyo Stock Exchange Section I stocks. More specifically, news about future dividends accounts for $88.6 \%$ of the total variance of unexpected returns in a VAR(2) model and $86 \%$ of the total variance in a VAR(3) model for Tokyo I stocks. ${ }^{20}$ The variation of real interest rates has a small impact on the variation of unexpected excess stock returns (accounting for $10.4 \%$ of the $\operatorname{Var}(e)$ under $\operatorname{VAR}(2)$ ). The variance of news about future expected returns impacts on the variance of stock returns to a

\footnotetext{
${ }^{20}$ See Appendix for the VAR specification and the computation of the return components. Here, we first perform a test of lag length of the VAR process. A simple Wald-test of the hypothesis that the coefficients on the last lagged variables are jointly zero is rejected for $\operatorname{VAR}(2)$ but not for $\operatorname{VAR}(3)$. Thus, the last lag is significant for $\operatorname{VAR}(2)$ but not significant for $\operatorname{VAR}(3)$. Therefore either a VAR(2) or VAR(3) process should be utilized in decomposing the variance of asset returns.
} 
greater extent $(24.1 \%)$.

Given the dynamics of asset returns, our next step is to study the trading (net purchase) behavior of Japanese market investors in relation to the dynamics of stock market returns. To be more specific, given that the return generating process is exogenous, we relate security trading to innovations about stocks' future dividends and expected future returns.

Panel B of Table 7 studies the relationship between net stock purchases and various components of excess stock returns. We can see from panel B.1 that the net purchases of investment trusts, corporations, and individuals are negatively correlated with future dividend growth, while the net purchases of securities firms' proprietary trading, insurance firms, and foreign investors are positively correlated with future dividend growths. This is quite interesting. Since news about future dividend growth reflects changes in the long-term value of Japanese stocks, our results suggest that relative to some Japanese market participants, foreign investors tend to be more long-term oriented, contrary to the claim that foreign investors tend to be shortterm investors who ignore long-term fundamentals.

Panel B.1 also presents evidence on the correlation between net stock purchases and news about future excess returns. Again, we see no evidence that foreign investors behave differently from domestic groups.

Panel B.2 presents the relationship between net stock purchases and various lagged components of excess stock returns. We can see that the net purchases of investment trusts, corporations, and individuals are negatively correlated with lagged future dividend growths, while the net purchases of security firms, insurance companies, banks, and foreign investors are positively correlated. We also have some weak evidence that foreign net purchases are related 
to lagged news about future excess returns. It is worth noting here that, when we regress net purchases on various components of excess returns, we find that these components explain only a small fraction of the variation in net purchases. ${ }^{21}$

\section{Conclusions}

This paper develops a comprehensive framework for analyzing the impact of foreign investment on domestic financial markets. First, we develop a three-stage-least-square estimation approach to examine the impact of foreign and domestic trading on market volatility. Second, we use net purchases of securities as a proxy for investors' forecasts of future excess returns, and apply the market timing test of Henriksson and Merton (1981) to evaluate the market timing performance of various investment groups in the Japanese market. Third, using the Campbell and Shiller (1988) approximate present value model, we decompose excess stock return innovations into news about future excess returns, dividend growths, and interest rates. We then study the relationship between different news components and foreign and domestic trading behaviors.

We find that foreign investment improves liquidity in the Japanese market. We find there is little empirical evidence that trading by foreign investors tends to increase market volatility any more than trading of domestic groups. There is also little evidence of superior foreign investor market timing abilities. Thus, the claim of exploitation of domestic investors by foreign investors has no empirical support. There is some weak evidence that foreign investment is sensitive to

\footnotetext{
${ }^{21}$ We have also studied the relationships among stock buying and selling activities with current and lagged components of stock excess returns. The results are similar to what we find for net purchase. These results are available upon request.
} 
long-term dividend news, contrary to the claim that foreign investors primarily aim at short-term gains while ignoring long-term fundamentals. Thus, we conclude that the long-term impact of foreign investment is mostly positive for the Japanese equity market. Therefore, our results support the view that international free flow of equity capital is beneficial to domestic markets.

Before drawing any policy implications from our conclusions, it is important to remember that the Japanese equity market is highly regulated. We also need to remember that, despite the fact that foreign investment plays an important role in the Japanese equity market, foreign ownership still accounts for less than $10 \%$ of total Japanese shares. As a result, our conclusions may not apply to many emerging markets which lack a rigorous regulatory system and a large domestic investment base to cushion the sudden outflow of foreign investment. Thus, although our results support the general theme of the GATT agreement that free trade in the financial service sector (especially international free capital flow) is beneficial to domestic markets, we caution against using the results to push for full and immediate opening of financial markets in less developed countries.

We view this study as a first step towards understanding the impact of foreign investment on domestic financial markets. Our contribution to the international finance literature is not its conclusion but a new framework for identifying the issues and systematically studying them. Our work provides future researchers with some useful information about data collection, econometric modeling and estimation procedures. It also provides some direction for future research, such as the need to develop a more comprehensive framework to evaluate the costs and benefits of foreign investment and the regulatory policy issue of how to balance the need for attracting foreign capital and maintaining domestic market stability. We hope our work will stimulate more theoretical and 
empirical work in this area. 


\section{Appendix}

The three-stage-least-square instrumental variables estimation is given in the following framework. We denote:

$$
Y=\left(v_{2}, v_{3}, \ldots, v_{T}\right)^{\prime}
$$

as $N \times 1$ vectors of observations for the monthly volatility.

Denote the variables on the right side of equation (1) as $X=\left(e, Y_{-1}, W\right), e$ as an $N \times 1$ vector of ones, $Y_{-1}$ is the lagged monthly volatility and $W$ is the vector of monthly transactions. $U=\left(u_{2}, u_{3}, \ldots u_{\downarrow}\right)^{\prime}$ as the transformed error terms, and $B=\left(b_{1} b_{2} b_{z}\right)^{\prime}$. Then (1) can be written as

$$
Y=X B+U
$$

Since $W_{-1}$ are orthogonal to the error terms in $(A 1)$, the following qualify as instrumental variables $Z=\left(e, Y_{-1}, W_{-1}\right)$.

To estimate (A1), we use a linear 3SLS procedure which is quite similar to the conventional 3SLS procedure for estimating simultaneous equations. In the first stage, a generalized instrumental variable estimation procedure is used to obtain a consistent estimate of $B$ of equation (A1):

$$
B=\left[W^{\prime} Z\left(Z^{\prime} Z\right)^{-1} Z^{\prime} W\right]^{-1} W^{\prime} Z\left(Z^{\prime} Z\right)^{-1} Z^{\prime} Y
$$

Using the above results, we then construct a more efficient estimate of $B$ in the second and third stage: 


$$
B=\left[W^{\prime} Z(G)^{-1} Z^{\prime} W\right]^{-1} W^{\prime} Z(G)^{-1} Z^{\prime} Y
$$

in which $G$ is the covariance matrix of $Z^{\prime} U$. See Newey and West (1987) for the calculation of G. The variance-covariance matrix of $B$ is given by $P=\operatorname{Var}(B)=\left[W^{\prime} Z(G)^{-1} Z^{\prime} W\right]^{-1}$. The estimate of $B$ given by $(A 3)$ is consistent despite the correlation between the autoregressors and the error terms, and the presence of heteroskedasticity and serial correlation. As pointed out by Holtz-Eakin, Newey, and Rosen (1988), the consistency is based mainly on the orthogonal condition that the error terms are uncorrelated with the instrumental variables used in estimating (A1). It is a special case of Hansen's (1982) GMM consistent estimator.

In order to implement our decomposition, we need to construct empirical proxies for the various excess return components in equation (3). To do this, we assume that $z_{t}$ is a vector of state variables which includes $\left(e_{t}, r_{t}\right)$ as its first two elements. $z_{t}$ also includes the relative bill rate (the current short term rate subtracted by its twelve months moving average), the term spread (the difference in the long-term government bond yield and the Gensaki rate), the dividend yield, and the industrial production growth rate. Next we assume that: $z_{t+1}=A z_{t}+w_{t+1}$, where $w_{t+1}$ is innovation in $z_{t+1}$. Under the above assumptions, it is easy to compute the following:

$$
\begin{gathered}
\tilde{e}_{e}=e_{1} \rho A(1-\rho A)^{-1} w_{t+1}, \\
\tilde{e_{r}}=e_{2} \rho A(1-\rho A)^{-1} w_{t+1} \\
\tilde{e}=e_{1} w_{t+1}, \\
\tilde{e}_{d}=\tilde{e}+\tilde{e}_{r}+\tilde{e}_{e}
\end{gathered}
$$

Where $e_{1}$ is a L-element column vector whose first element is one and whose other elements are all zero. $e_{2}$ is a L-element column vector whose second element is one and whose other elements 
are all zero. See Campbell and Hamao (1992), Campbell and Ammer (1993), and Campbell and Mei (1993) for the derivation of the above equation and the selection of state variables. 


\section{References}

Bekaert, Geert and Robert J. Hodrick, 1992, "Characterizing Predictable Components in Excess Returns on Equity and Foreign Exchange Markets,” Journal of Finance 47:467-510.

Bailey, Warren and Julapa Jagtiani, 1994, "Foreign Ownership Restrictions and Stock Prices in the Thai Capital Market," Journal of Financial Economics 36:57-87.

Bailey, Warren and René M. Stulz, 1990, "Benefits Of International Diversification: The Case Of Pacific Basin Stock Markets," Journal of Portfolio Management 16(4):57-61.

Brenner, Menachem, Marti G. Subrahmanyam, and Jun Uno, 1989, “The Behavior of Prices in the Nikkei Spot and Futures Market," Journal of Financial Economics 23:363-383.

Campbell, John Y. and John Ammer, 1993, "What Moves the Stock and Bond Markets? A Variance Decomposition for Long-Term Asset Returns," Journal of Finance forthcoming.

Campbell, John Y. and Yasushi Hamao, 1992, "Predictable Returns in the United States and Japan: A Study of Long Term Capital Markets Integration," Journal of Finance 47:43-70.

Campbell, John Y. and Jianping Mei, 1993, "Where Do Betas Come From? Asset Price Dynamics and the Sources of Systematic Risk," Review of Financial Studies 6:567-592.

Eun, Cheol S. and Bruce G. Resnick, 1988, "Exchange Rate Uncertainty, Forward Contracts, And International Portfolio Selection," Journal of Finance 43:197-215.

Fama, Eugene F. and Kenneth R. French, 1989, "Business Conditions and Expected Returns on Stocks and Bonds," Journal of Financial Economics 25:23-49.

Grauer, Robert R. and Nils H. Hakansson, 1987, "Gains from International Diversification: 1968-85 Returns on Portfolios of Stocks and Bonds," Journal of Finance 42:721-739.

Hamao, Yasushi and Roger G. Ibbotson, 1989, SBI Japan (with updates), Ibbotson Associates.

Hardy, Daniel, 1990, "Market Timing and International Diversification," Journal of Portfolio Management 16(4):23-27.

Hansen, Lars Peter, 1982, "Large Sample Properties of Generalized Method of Moments Estimators," Econometrica 50:1029-1054.

Harvey, Campbell, 1995, "Predictable Risk and Returns in Emerging Markets," Review of Financial Studies, 8. 
Henriksson, Roy D. and Robert C. Merton, 1981, "On Market Timing and Investment Performance II: Statistical Procedures for Evaluating Forecasting Skills,” Journal of Business 54:513-533.

Henriksson, Roy D., 1984, "Market Timing and Mutual Fund Performance: An Empirical Investigation," Journal of Business 57:73-96.

Holtz-Eakin, Douglas, Whitney Newey, and Harvey Rosen, 1988, "Estimating Vector Autoregression with Panel Data," Econometrica 56:1371-1395.

Ibbotson Associates, 1994, Stocks, Bonds, Bills, and Inflation.

Kang, Jun-Koo and René Stulz, 1995, "Why is There a Home-Bias?: An Analysis of Foreign Equity Portfolio Investment in Japan," Working Paper, Ohio State University.

Keim, Donald B. and Robert F. Stambaugh, 1986, "Predicting Returns in the Stock and Bond Markets," Journal of Financial Economics 17:357-390.

Merton, Robert C., 1981, "On Market Timing and Investment Performance I: An Equilibrium Theory of Value for Market Forecasts," Journal of Business 54:363-406.

Miller, Merton H., 1994, “Financial Regulation,” Pacific Basin Finance Journal 2:91-106.

Newey, Whitney, and Kenneth West, 1987, "A Simple, Positive Semi-Definite, Heteroskedasticity and Autocorrelation Consistent Covariance Matrix," Econometrica 55:703-708.

Obstfeld, Maurice, 1994, "Risk Taking, Global Diversification, and Growth," American Economic Review 84:1310-1329.

Stulz, René, 1987, "An Equilibrium Model of Exchange Rate Determination and Asset Pricing with Non-traded Goods and Imperfect Information,” Journal of Political Economy 95:1024-1040.

Tokyo Stock Exchange, 1975-1993, Tokyo Stock Exchange Monthly Statistics.

Tokyo Stock Exchange, 1994a, Tokyo Stock Exchange Annual Bulletin.

Tokyo Stock Exchange, 1994b, TSE Fact Book.

White, Halbert, 1984, Asymptotic Theory for Econometricians, Academic Press: Orlando, Florida. 
Table 1

Trading by Various Investor Types for 1975, 1988, and 1991

\begin{tabular}{|l|c|c|c|c|c|c|c|c|c|}
\hline & \multicolumn{3}{|c|}{ Purchase (\%) } & \multicolumn{3}{c|}{ Sales (\%) } & \multicolumn{3}{c|}{ Net Investment (Bi. Yen) } \\
\cline { 2 - 11 } & 1975 & 1988 & 1991 & 1975 & 1988 & 1991 & 1975 & 1988 & 1991 \\
\hline \hline $\begin{array}{l}\text { Securities } \\
\text { Firms }\end{array}$ & 19.2 & 22.8 & 24.9 & 18.8 & 22.1 & 23.1 & -15 & -142 & 2,645 \\
\hline Insurance & 1.3 & 1.0 & 1.9 & 1.2 & 0.5 & 1.9 & 8 & 1,220 & 106 \\
\hline Banks & 1.0 & 19.8 & 12.9 & 0.9 & 18.7 & 12.3 & 6 & 1,170 & 1,041 \\
\hline $\begin{array}{l}\text { Other Financial } \\
\text { Institutions }\end{array}$ & 0.2 & 1.0 & 0.4 & 0.3 & 1.0 & 0.8 & -7 & -12 & -386 \\
\hline $\begin{array}{l}\text { Investment } \\
\text { Trusts }\end{array}$ & 6.2 & 9.1 & 10.6 & 4.6 & 8.8 & 12.3 & 135 & 45 & $-1,094$ \\
\hline $\begin{array}{l}\text { Non-Financial } \\
\text { Corporations }\end{array}$ & 6.0 & 10.9 & 6.5 & 8.0 & 11.2 & 8.5 & -220 & $-1,810$ & $-1,545$ \\
\hline $\begin{array}{l}\text { Other } \\
\text { Corporations }\end{array}$ & 0.9 & 0.9 & 0.8 & 0.5 & 0.8 & 0.5 & 38 & 206 & 376 \\
\hline $\begin{array}{l}\text { Non-member } \\
\text { Securities } \\
\text { Firms }\end{array}$ & 2.4 & 2.5 & 2.8 & 2.4 & 2.6 & 3.1 & -8 & -444 & -207 \\
\hline Individuals & 57.5 & 23.9 & 22.1 & 59.1 & 59.1 & 25.1 & -334 & $-5,342$ & $-1,876$ \\
\hline Foreigners & 5.2 & 8.1 & 17.0 & 4.0 & 4.0 & 12.5 & 105 & $-3,993$ & 4,995 \\
\hline
\end{tabular}

Note: Trading volume (in yen) on the Tokyo Stock Exchange by "integrated securities firms," who are capable of sales, underwriting, dealing, and brokerage. Percentage volume is computed out of the total of all investor groups. Data are collected from Tokyo Stock Exchange Monthly Bulletin. 
Table 2

Correlation Among Net Purchases of Various Investor Groups

Monthly, 1974:07 - 1992:06

\begin{tabular}{|l|c|l|l|l|l|l|l|}
\hline & $\begin{array}{l}\text { Securities } \\
\text { Firms }\end{array}$ & $\begin{array}{l}\text { Insurance } \\
\text { Firms }\end{array}$ & Banks & $\begin{array}{l}\text { Investment } \\
\text { Trusts }\end{array}$ & Corporations & Individuals & Foreigners \\
\hline $\begin{array}{l}\text { Securities } \\
\text { Firms }\end{array}$ & 1.00 & & & & & & \\
\hline $\begin{array}{l}\text { Insurance } \\
\text { Firms }\end{array}$ & 0.07 & 1.00 & & & & & \\
\hline Banks & 0.28 & 0.26 & 1.00 & & & & \\
\hline $\begin{array}{l}\text { Investment } \\
\text { Trusts }\end{array}$ & -0.02 & 0.05 & 0.01 & 1.00 & & & \\
\hline Corporations & -0.24 & 0.01 & 0.09 & 0.09 & 1.00 & & \\
\hline Individuals & -0.41 & -0.21 & -0.25 & -0.25 & 0.40 & 1.00 & \\
\hline Foreigners & -0.44 & -0.21 & -0.32 & -0.33 & 0.52 & -0.13 & 1.00 \\
\hline
\end{tabular}

Note: Net purchases are computed from monthly trading volume data (in yen) on the Tokyo Stock Exchange by "integrated securities firms." Original data are collected from Tokyo Stock Exchange Monthly Bulletin. 
Table 3

Regression of Volatility on Lagged Volatility and Contemporaneous Purchases

\begin{tabular}{|l|c|c|c|c|c|c|c|c|c|c|}
\hline & $b_{1}$ & $b_{2}$ & $\begin{array}{l}\text { Securities } \\
\text { Firms }\end{array}$ & $\begin{array}{l}\text { Insurance } \\
\text { Firms }\end{array}$ & Banks & $\begin{array}{l}\text { Invest. } \\
\text { Trusts }\end{array}$ & $\begin{array}{l}\text { Corpora- } \\
\text { tions }\end{array}$ & $\begin{array}{l}\text { Individ- } \\
\text { uals }\end{array}$ & $\begin{array}{l}\text { Foreign- } \\
\text { ers }\end{array}$ & $\overline{R^{2}}$ \\
\hline $\begin{array}{l}\text { Net } \\
\text { Buy }\end{array}$ & $\begin{array}{c}0.64 \\
(6.18)\end{array}$ & $\begin{array}{c}0.28 \\
(5.95)\end{array}$ & $\begin{array}{c}0.51 \\
(3.52)\end{array}$ & $\begin{array}{c}0.09 \\
(0.35)\end{array}$ & $\begin{array}{c}0.55 \\
(3.43)\end{array}$ & $\begin{array}{c}0.49 \\
(3.02)\end{array}$ & $\begin{array}{c}0.69 \\
(3.29)\end{array}$ & $\begin{array}{c}0.76 \\
(3.85)\end{array}$ & $\begin{array}{c}0.44 \\
(3.20)\end{array}$ & 0.31 \\
\hline Buy & $\begin{array}{c}0.30 \\
(0.09)\end{array}$ & $\begin{array}{c}0.32 \\
(6.69)\end{array}$ & $\begin{array}{c}0.23 \\
(0.21)\end{array}$ & $\begin{array}{c}1.36 \\
(2.18)\end{array}$ & $\begin{array}{c}-0.36 \\
(-0.6)\end{array}$ & $\begin{array}{c}-0.09 \\
(-0.1)\end{array}$ & $\begin{array}{c}0.58 \\
(0.52)\end{array}$ & $\begin{array}{c}-1.48 \\
(-1.1)\end{array}$ & $\begin{array}{c}0.15 \\
(0.38)\end{array}$ & 0.27 \\
\hline Sale & $\begin{array}{c}2.13 \\
(0.71)\end{array}$ & $\begin{array}{c}0.26 \\
(5.62)\end{array}$ & $\begin{array}{c}0.91 \\
(0.82)\end{array}$ & $\begin{array}{c}0.94 \\
(2.10)\end{array}$ & $\begin{array}{c}-0.79 \\
(-1.5)\end{array}$ & $\begin{array}{c}0.80 \\
(1.57)\end{array}$ & $\begin{array}{c}0.10 \\
(0.11)\end{array}$ & $\begin{array}{c}-2.86 \\
(-2.5)\end{array}$ & $\begin{array}{c}1.03 \\
(2.31)\end{array}$ & 0.33 \\
\hline
\end{tabular}

Note: The table reports regression coefficients from the regression

$$
v_{t}=b_{1}+b_{2} v_{t-1}+b_{3} w_{t}+u_{t} \text {, }
$$

where $v_{t}$ is the monthly volatility for month $t, w_{t}$ is the vector of monthly transactions, and $u_{t}$ is the error term. The t-statistics (in parentheses) are computed by the three-stage-least-square approach to adjust for possible endogeneity. 
Table 4

Trading Activities and Future Excess Returns

Panel A

Regression of Net Purchases on Lagged Net Purchases and Future Excess Returns (1 month)

\begin{tabular}{|c|c|c|c|c|}
\hline & $\begin{array}{c}c_{1} \\
\text { (t-stat) }\end{array}$ & $\begin{array}{c}c_{2} \\
\text { (t-stat) }\end{array}$ & $\begin{array}{c}c_{3} \\
\text { (t-stat) }\end{array}$ & $\overline{R^{2}}$ \\
\hline $\begin{array}{l}\text { Securities } \\
\text { Firms }\end{array}$ & $\begin{array}{c}0.39 \\
(3.08)\end{array}$ & $\begin{array}{c}0.70 \\
(13.87)\end{array}$ & $\begin{array}{c}-1.00 \\
(-0.45)\end{array}$ & 0.48 \\
\hline $\begin{array}{l}\text { Insurance } \\
\text { Firms }\end{array}$ & $\begin{array}{c}0.06 \\
(2.66)\end{array}$ & $\begin{array}{c}0.57 \\
(10.0)\end{array}$ & $\begin{array}{c}-0.17 \\
(-0.37)\end{array}$ & 0.31 \\
\hline Banks & $\begin{array}{c}0.25 \\
(2.19)\end{array}$ & $\begin{array}{c}0.56 \\
(9.66)\end{array}$ & $\begin{array}{c}1.16 \\
(0.52)\end{array}$ & 0.31 \\
\hline $\begin{array}{l}\text { Investment } \\
\text { Trusts }\end{array}$ & $\begin{array}{c}0.13 \\
(1.45)\end{array}$ & $\begin{array}{c}0.47 \\
(7.65)\end{array}$ & $\begin{array}{c}0.97 \\
(0.52)\end{array}$ & 0.21 \\
\hline Corporations & $\begin{array}{c}-0.12 \\
(-2.39)\end{array}$ & $\begin{array}{c}0.37 \\
(5.77)\end{array}$ & $\begin{array}{c}-0.72 \\
(-0.72)\end{array}$ & 0.13 \\
\hline Individuals & $\begin{array}{c}-0.47 \\
(-3.51)\end{array}$ & $\begin{array}{c}0.51 \\
(8.71)\end{array}$ & $\begin{array}{c}-1.96 \\
(-0.79)\end{array}$ & 0.26 \\
\hline Foreigners & $\begin{array}{c}-0.23 \\
(-1.44)\end{array}$ & $\begin{array}{c}0.69 \\
(13.53)\end{array}$ & $\begin{array}{c}3.24 \\
(0.99)\end{array}$ & 0.46 \\
\hline
\end{tabular}

The table reports regression coefficients from

$$
P U R_{t}=c_{1}+c_{2} P U R_{t-1}+c_{3} e_{t+1}+\epsilon_{t},
$$

where $P U R_{t}$ is net purchases for month $t$ and $e_{t+1}$ are future excess returns (in excess of short rate) for months $t+1$, respectively. Sample period 1974:07 - 1992:06. 
Table 4 (continued)

Panel B

Regression of Net Purchases on Lagged Net Purchases and Future Excess Returns (3 months)

\begin{tabular}{|c|c|c|c|c|}
\hline & $\begin{array}{c}c_{1} \\
\text { (t-stat) }\end{array}$ & $\begin{array}{c}c_{2} \\
\text { (t-stat) }\end{array}$ & $\begin{array}{c}c_{3} \\
\text { (t-stat) }\end{array}$ & $\overline{R^{2}}$ \\
\hline $\begin{array}{l}\text { Securities } \\
\text { Firms }\end{array}$ & $\begin{array}{c}0.41 \\
(3.25)\end{array}$ & $\begin{array}{c}0.70 \\
(13.88)\end{array}$ & $\begin{array}{c}-0.25 \\
(-0.20)\end{array}$ & 0.48 \\
\hline $\begin{array}{l}\text { Insurance } \\
\text { Firms }\end{array}$ & $\begin{array}{c}0.07 \\
(2.61)\end{array}$ & $\begin{array}{c}0.57 \\
(9.74)\end{array}$ & $\begin{array}{c}-0.05 \\
(-0.18)\end{array}$ & 0.31 \\
\hline Banks & $\begin{array}{c}0.23 \\
(2.00)\end{array}$ & $\begin{array}{c}0.56 \\
(9.93)\end{array}$ & $\begin{array}{c}2.28 \\
(1.81)\end{array}$ & 0.33 \\
\hline $\begin{array}{l}\text { Investment } \\
\text { Trusts }\end{array}$ & $\begin{array}{c}0.11 \\
(1.23)\end{array}$ & $\begin{array}{c}0.46 \\
(7.39)\end{array}$ & $\begin{array}{c}1.47 \\
(1.35)\end{array}$ & 0.22 \\
\hline Corporations & $\begin{array}{c}-0.13 \\
(-2.42)\end{array}$ & $\begin{array}{c}0.37 \\
(5.67)\end{array}$ & $\begin{array}{c}0.16 \\
(0.27)\end{array}$ & 0.13 \\
\hline Individuals & $\begin{array}{c}-0.49 \\
(-3.56)\end{array}$ & $\begin{array}{c}0.51 \\
(8.61)\end{array}$ & $\begin{array}{c}-0.21 \\
(-0.15)\end{array}$ & 0.26 \\
\hline Foreigners & $\begin{array}{c}-0.21 \\
(-1.30)\end{array}$ & $\begin{array}{c}0.67 \\
(12.79)\end{array}$ & $\begin{array}{c}-2.41 \\
(-1.25)\end{array}$ & 0.46 \\
\hline
\end{tabular}

The table reports regression coefficients from

$$
P U R_{t}=c_{1}+c_{2} P U R_{t-1}+c_{3} e_{t+1, t+3}+\epsilon_{t},
$$

where $P U R_{t}$ is net purchases for month $t$ and $e_{t+1, t+3}$ are future excess returns (in excess of short rate) for 3 months (from $t+1$ to $t+3$ ), respectively. Sample period 1974:07 - 1992:06. 
Table 4 (continued)

Panel C

Regression of Net Purchases on Lagged Net Purchases and Future Excess Returns (6 months)

\begin{tabular}{|c|c|c|c|c|}
\hline & $\begin{array}{c}c_{1} \\
\text { (t-stat) }\end{array}$ & $\begin{array}{c}c_{2} \\
\text { (t-stat) }\end{array}$ & $\begin{array}{c}c_{3} \\
\text { (t-stat) }\end{array}$ & $\overline{R^{2}}$ \\
\hline $\begin{array}{l}\text { Securities } \\
\text { Firms }\end{array}$ & $\begin{array}{c}0.40 \\
(3.08)\end{array}$ & $\begin{array}{c}0.69 \\
(13.66)\end{array}$ & $\begin{array}{c}0.42 \\
(0.47)\end{array}$ & 0.48 \\
\hline $\begin{array}{l}\text { Insurance } \\
\text { Firms }\end{array}$ & $\begin{array}{c}0.08 \\
(3.17)\end{array}$ & $\begin{array}{c}0.53 \\
(8.91)\end{array}$ & $\begin{array}{c}-0.25 \\
(-1.29)\end{array}$ & 0.30 \\
\hline Banks & $\begin{array}{c}0.23 \\
(1.95)\end{array}$ & $\begin{array}{c}0.56 \\
(9.72)\end{array}$ & $\begin{array}{c}1.43 \\
(1.59)\end{array}$ & 0.33 \\
\hline $\begin{array}{l}\text { Investment } \\
\text { Trusts }\end{array}$ & $\begin{array}{c}0.12 \\
(1.26)\end{array}$ & $\begin{array}{c}0.46 \\
(7.47)\end{array}$ & $\begin{array}{c}0.99 \\
(1.30)\end{array}$ & 0.21 \\
\hline Corporations & $\begin{array}{c}-0.12 \\
(-2.32)\end{array}$ & $\begin{array}{c}0.36 \\
(5.50)\end{array}$ & $\begin{array}{c}0.12 \\
(0.29)\end{array}$ & 0.12 \\
\hline Individuals & $\begin{array}{c}-0.48 \\
(-3.44)\end{array}$ & $\begin{array}{c}0.51 \\
(8.56)\end{array}$ & $\begin{array}{c}-0.54 \\
(-0.53)\end{array}$ & 0.26 \\
\hline Foreigners & $\begin{array}{c}-0.21 \\
(-1.27)\end{array}$ & $\begin{array}{c}0.66 \\
(12.61)\end{array}$ & $\begin{array}{c}-1.67 \\
(-1.22)\end{array}$ & 0.46 \\
\hline
\end{tabular}

The table reports regression coefficients from

$$
P U R_{t}=c_{1}+c_{2} P U R_{t-1}+c_{3} e_{t+1, t+6}+\epsilon_{t},
$$

where $P U R_{t}$ is net purchases for month $t$ and $e_{t+1, t+6}$ are future excess returns (in excess of short rate) for 6 months (from $t+1$ to $t+6$ ), respectively. Sample period 1974:07 - 1992:06. 
Table 5

Market Timing Tests

Panel A

Sample Period: 1974:07-1992:06

\begin{tabular}{|l|c|c|c|c|c|c|}
\hline \multirow{2}{*}{} & \multicolumn{3}{|c|}{ Forecast over short rate } & \multicolumn{2}{c|}{ Forecast over S\&P 500 in dollar } \\
\cline { 2 - 7 } & $p_{1}+p_{2}$ & std. & t-test & $p_{1}+p_{2}$ & std. & t-test \\
\hline Securities Firms & 1.003 & 0.026 & 0.123 & 1.003 & 0.026 & 0.103 \\
\hline Insurance Firms & 0.991 & 0.041 & -0.219 & 0.989 & 0.041 & -0.257 \\
\hline Banks & 1.074 & 0.037 & 2.020 & 1.051 & 0.037 & 1.390 \\
\hline Investment Trusts & 1.005 & 0.047 & 0.096 & 0.987 & 0.047 & -0.284 \\
\hline Corporations & 0.882 & 0.046 & -2.581 & 0.851 & 0.046 & -3.279 \\
\hline Individuals & 0.910 & 0.035 & -2.565 & 0.966 & 0.035 & -0.966 \\
\hline Foreigners & 1.049 & 0.048 & 1.021 & 1.015 & 0.047 & 0.314 \\
\hline
\end{tabular}

Panel B

Sample Period: 1974:07-1983:12

\begin{tabular}{|l|c|c|c|c|c|c|}
\hline \multirow{2}{*}{} & \multicolumn{3}{|c|}{ Forecast over short rate } & \multicolumn{3}{c|}{ Forecast over S\&P 500 in dollar } \\
\cline { 2 - 7 } & $p_{1}+p_{2}$ & std. & t-test & $p_{1}+p_{2}$ & std. & t-test \\
\hline Securities Firms & 0.967 & 0.018 & -1.885 & 0.964 & 0.018 & -2.062 \\
\hline Insurance Firms & 0.980 & 0.044 & -0.455 & 1.064 & 0.044 & 1.459 \\
\hline Banks & 0.999 & 0.046 & -0.028 & 1.011 & 0.045 & 0.235 \\
\hline Investment Trusts & 0.909 & 0.066 & -1.389 & 0.872 & 0.066 & -1.947 \\
\hline Corporations & 0.778 & 0.064 & -3.456 & 0.842 & 0.064 & -2.476 \\
\hline Individuals & 1.020 & 0.044 & 0.455 & 1.007 & 0.044 & 0.149 \\
\hline Foreigners & 1.142 & 0.066 & 2.129 & 1.005 & 0.066 & 0.080 \\
\hline
\end{tabular}


Table 5 (continued)

Panel C

Sample Period: 1984:01-1992:06

\begin{tabular}{|l|c|c|c|c|c|c|}
\hline \multirow{2}{*}{} & \multicolumn{3}{|c|}{ Forecast over short rate } & \multicolumn{3}{c|}{ Forecast over S\&P 500 in dollar } \\
\cline { 2 - 7 } & $p_{1}+p_{2}$ & std. & t-test & $p_{1}+p_{2}$ & std. & t-test \\
\hline Securities Firms & 1.049 & 0.050 & 0.972 & 1.042 & 0.050 & 0.883 \\
\hline Insurance Firms & 1.012 & 0.068 & 0.182 & 0.898 & 0.068 & -1.500 \\
\hline Banks & 1.161 & 0.058 & 2.764 & 1.093 & 0.058 & 1.594 \\
\hline Investment Trusts & 1.109 & 0.068 & 1.612 & 1.116 & 0.067 & 1.715 \\
\hline Corporations & 0.999 & 0.065 & -0.012 & 0.859 & 0.065 & -2.174 \\
\hline Individuals & 0.785 & 0.055 & -3.888 & 0.924 & 0.055 & -1.389 \\
\hline Foreigners & 0.948 & 0.068 & -0.762 & 1.023 & 0.068 & 0.341 \\
\hline
\end{tabular}

Panel D

Sample Period: 1989:01-1992:06

\begin{tabular}{|l|c|c|c|c|c|c|}
\hline \multirow{2}{*}{} & \multicolumn{3}{|c|}{ Forecast over short rate } & \multicolumn{3}{c|}{ Forecast over S\&P 500 in dollar } \\
\cline { 2 - 7 } & $p_{1}+p_{2}$ & std. & t-test & $p_{1}+p_{2}$ & std. & t-test \\
\hline Securities Firms & 0.908 & 0.110 & -0.836 & 0.893 & 0.118 & -0.906 \\
\hline Insurance Firms & 1.047 & 0.111 & 0.423 & 1.036 & 0.120 & 0.298 \\
\hline Banks & 1.127 & 0.113 & 1.121 & 1.000 & 0.122 & 0.000 \\
\hline Investment Trusts & 1.169 & 0.113 & 1.495 & 1.107 & 0.122 & 0.877 \\
\hline Corporations & 1.092 & 0.110 & 0.836 & 1.107 & 0.118 & 0.906 \\
\hline Individuals & 0.835 & 0.108 & -1.526 & 1.036 & 0.116 & 0.307 \\
\hline Foreigners & 0.948 & 0.111 & -0.465 & 1.036 & 0.120 & 0.298 \\
\hline
\end{tabular}

Note: $p_{1}(t)$ is the conditional probability of a correct forecast, given that $Z_{M}(t) \leq R(t)$, and $p_{2}(t)$ is the conditional probability of a correct forecast, given that $Z_{M}(t)>R(t)$, where $Z_{M}(t)$ is the return on value-weighted index of Tokyo Stock Exchange Section I stocks and $R(t)$ is the short interest rate or the return on S\&P 500 index in dollar. 
Table 6

Regression of Net Purchases on Lagged Net Purchases and Past Excess Returns

\begin{tabular}{|c|c|c|c|c|c|c|}
\hline & $\begin{array}{c}g_{1} \\
\text { (t-stat) }\end{array}$ & $\begin{array}{c}g_{2} \\
\text { (t-stat) }\end{array}$ & $\begin{array}{c}g_{3} \\
\text { (t-stat) }\end{array}$ & $\begin{array}{c}g_{4} \\
\text { (t-stat) }\end{array}$ & $\begin{array}{c}g_{5} \\
\text { (t-stat) }\end{array}$ & $\overline{R^{2}}$ \\
\hline $\begin{array}{l}\text { Securities } \\
\text { Firms }\end{array}$ & $\begin{array}{c}0.41 \\
(3.19)\end{array}$ & $\begin{array}{c}0.69 \\
(12.98)\end{array}$ & $\begin{array}{c}-0.76 \\
(-0.33)\end{array}$ & $\begin{array}{c}1.56 \\
(0.69)\end{array}$ & $\begin{array}{c}0.03 \\
(0.02)\end{array}$ & 0.47 \\
\hline $\begin{array}{l}\text { Insurance } \\
\text { Firms }\end{array}$ & $\begin{array}{c}0.06 \\
(2.34)\end{array}$ & $\begin{array}{c}0.55 \\
(9.55)\end{array}$ & $\begin{array}{c}1.03 \\
(2.21)\end{array}$ & $\begin{array}{c}0.45 \\
(0.94)\end{array}$ & $\begin{array}{c}0.65 \\
(1.38)\end{array}$ & 0.34 \\
\hline Banks & $\begin{array}{c}0.22 \\
(1.92)\end{array}$ & $\begin{array}{c}0.51 \\
(8.88)\end{array}$ & $\begin{array}{l}4.51 \\
(2.04)\end{array}$ & $\begin{array}{c}4.54 \\
(2.03)\end{array}$ & $\begin{array}{c}5.66 \\
(2.51)\end{array}$ & 0.34 \\
\hline $\begin{array}{l}\text { Investment } \\
\text { Trusts }\end{array}$ & $\begin{array}{c}0.13 \\
(1.35)\end{array}$ & $\begin{array}{c}0.47 \\
(7.55)\end{array}$ & $\begin{array}{c}-0.49 \\
(-0.25)\end{array}$ & $\begin{array}{c}0.91 \\
(0.48)\end{array}$ & $\begin{array}{c}1.86 \\
(0.98)\end{array}$ & 0.21 \\
\hline Corporations & $\begin{array}{c}-0.14 \\
(-2.70)\end{array}$ & $\begin{array}{c}0.39 \\
(5.63)\end{array}$ & $\begin{array}{c}0.37 \\
(0.34)\end{array}$ & $\begin{array}{c}-0.15 \\
(-0.15)\end{array}$ & $\begin{array}{c}3.06 \\
(3.04)\end{array}$ & 0.16 \\
\hline Individuals & $\begin{array}{c}-0.47 \\
(-3.51)\end{array}$ & $\begin{array}{c}0.50 \\
(8.02)\end{array}$ & $\begin{array}{c}-4.96 \\
(-1.95)\end{array}$ & $\begin{array}{c}2.33 \\
(-0.91)\end{array}$ & $\begin{array}{c}-3.40 \\
(-1.36)\end{array}$ & 0.28 \\
\hline Foreigners & $\begin{array}{c}-0.12 \\
(-0.77)\end{array}$ & $\begin{array}{c}0.68 \\
(13.70)\end{array}$ & $\begin{array}{c}-6.47 \\
(-2.05)\end{array}$ & $\begin{array}{l}-13.05 \\
(-4.21)\end{array}$ & $\begin{array}{c}-7.92 \\
(-2.49)\end{array}$ & 0.52 \\
\hline
\end{tabular}

The table reports regression coefficients from

$$
P U R_{t}=g_{1}+g_{2} P U R_{t-1}+g_{3} e_{t-1}+g_{4} e_{t-2}+g_{5} e_{t-3}+\epsilon_{t},
$$

where $P U R_{t}$ is net purchases for month $t$ and $e_{t-1}, e_{t-2}$ and $e_{t-3}$ are past excess returns (in excess of short rate) for months $t-1, t-2$, and $t-3$, respectively. Sample period 1974:07 - 1992:06. 
Table 7

Excess Return Decomposition and Trading Activities

Panel A

Decomposition of Excess Stock Returns

\begin{tabular}{|l|c|c|c|c|}
\hline \multirow{2}{*}{} & \multicolumn{2}{|c|}{ VAR with 2 Lags } & \multicolumn{2}{c|}{ VAR with 3 Lags } \\
\cline { 2 - 5 } & point estimate & $\begin{array}{c}\text { asymptotic } \\
\text { standard error }\end{array}$ & point estimate & $\begin{array}{c}\text { asymptotic } \\
\text { standard error }\end{array}$ \\
\hline $\operatorname{var}\left(\tilde{e}_{d}\right)$ & 0.886 & 0.581 & 0.860 & 0.642 \\
\hline $\operatorname{var}\left(\tilde{e}_{r}\right)$ & 0.104 & 0.103 & 0.133 & 0.164 \\
\hline $\operatorname{var}\left(\tilde{e}_{e}\right)$ & 0.241 & 0.360 & 0.304 & 0.401 \\
\hline$-2 \operatorname{cov}\left(\tilde{e}_{d}, \tilde{e_{r}}\right)$ & -0.402 & 0.462 & -0.445 & 0.618 \\
\hline$-2 \operatorname{cov}\left(\tilde{e}_{d}, \tilde{e_{e}}\right)$ & 0.410 & 0.223 & 0.378 & 0.266 \\
\hline $2 \operatorname{cov}\left(\tilde{e}_{r}, \tilde{e_{e}}\right)$ & -0.239 & 0.225 & -0.230 & 0.314 \\
\hline $\operatorname{corr}\left(\tilde{e}_{d}, \tilde{e_{r}}\right)$ & 0.662 & 0.292 & 0.658 & 0.364 \\
\hline $\operatorname{corr}\left(\tilde{e}_{d}, \tilde{e_{e}}\right)$ & -0.443 & 0.326 & -0.370 & 0.309 \\
\hline $\operatorname{corr}\left(\tilde{e}_{r}, \tilde{e_{e}}\right)$ & -0.753 & 0.179 & -0.571 & 0.417 \\
\hline
\end{tabular}

Note: Unexpected excess stock returns are decomposed into $\tilde{e}_{d}, \tilde{e}_{r}$ and $\tilde{e}_{e}$ representing components due to innovation in future dividends, interest rates, and future excess returns. Sample period 1974:07 -1992:06. The state variables in the VAR process include excess stock returns, the real interest rate, the relative bill rate (the current short term rate subtracted by its twelve months moving average), the term spread (the difference in the long-term government bond yield and the Gensaki rate), the dividend yield, and the industrial production growth rate. 
Table 7 (continued)

Panel B

Relation between Net Purchase and Components of Excess Returns

B-1: Contemporaneous Relation

\begin{tabular}{|l|c|c|c|c|}
\hline & $\begin{array}{c}\text { corr }\left(P U R, \tilde{e}_{d}\right) \\
\text { (standard error) }\end{array}$ & $R^{2}$ & $\begin{array}{c}\text { corr }\left(P U R, \tilde{e}_{e}\right) \\
\text { (standard error) }\end{array}$ & $R^{2}$ \\
\hline Securities Firms & $\begin{array}{c}0.253 \\
(0.037)\end{array}$ & 0.064 & $\begin{array}{c}-0.134 \\
(0.102)\end{array}$ & 0.018 \\
\hline Insurance Firms & $\begin{array}{c}0.050 \\
(0.031)\end{array}$ & 0.003 & $\begin{array}{c}-0.025 \\
(0.059)\end{array}$ & 0.001 \\
\hline Banks & $\begin{array}{c}0.036 \\
(0.034)\end{array}$ & 0.001 & $\begin{array}{c}-0.031 \\
(0.057)\end{array}$ & 0.001 \\
\hline Investment & $\begin{array}{c}-0.184 \\
\text { Trusts }\end{array}$ & 0.034 & $\begin{array}{c}-0.039 \\
(0.084)\end{array}$ & 0.002 \\
\hline Corporations & $\begin{array}{c}-0.392 \\
\left(0 . b_{1} 038\right)\end{array}$ & 0.154 & $\begin{array}{c}0.100 \\
(0.124)\end{array}$ & 0.010 \\
\hline Individuals & $\begin{array}{c}-0.229 \\
(0.032)\end{array}$ & 0.052 & $\begin{array}{c}0.119 \\
(0.081)\end{array}$ & 0.014 \\
\hline Foreigners & $\begin{array}{c}0.214 \\
(0.022)\end{array}$ & 0.046 & $\begin{array}{c}-0.007 \\
(0.076)\end{array}$ & 0.000 \\
\hline
\end{tabular}

